\title{
Comparison of 10-Day Course of Triple Therapy Versus 14-Day Course for Eradication of Helicobacter pylori Infection in an Indonesian Population: Double-Blinded Randomized Clinical Trial
}

\author{
Ryan Herardi ${ }^{1}$, Ari Fahrial Syam ${ }^{2 *}$, Marcellus Simadibrata ${ }^{2}$, Siti Setiati ${ }^{3}$, Nikko \\ Darnindro ${ }^{4}$, Murdani Abdullah², Dadang Makmun²
}

\begin{abstract}
Objective: The aim of this study was to compare the effectiveness of 10-day course of triple therapy versus a 14-day course in the treatment of H.pylori infection in an Indonesian population. Methods: A double-blinded randomized clinical trial was included patients, Indonesian population, with H.pylori infection conducted in Cipto Mangunkusumo Hospital, Jakarta; Cilincing District General Hospital, Jakarta; and West Nusa Tenggara General Hospital, Mataram, during October 2016 - April 2017. Patients were randomized to be given triple therapy as Rabeprazole $20 \mathrm{mg}$, Amoxicillin $1,000 \mathrm{mg}$, and Clarithromycin $500 \mathrm{mg}$ twice daily, for 14 days or 10 days plus 4 days placebo. Eradication was evaluated with UBT at least 4 weeks after completion the therapy. Results: A total of 75 patients (38 in the 14-day group and 37 in the 10-day group) were included to the study. In the intention-to-threat analysis, eradication rate was $67.6 \%(95 \% \mathrm{CI}$. $52.5 \%-82.6 \%)$ for the 10-day group versus $86.8 \%(95 \%$ CI. $76.0 \%-97.5 \%)$ for the 14-day group $(\mathrm{p}=0.046)$, whereas per protocol analysis obtained $73.5 \%$ (95\% CI. 58.6\%-88.3\%) for the 10-day versus $91.9 \%$ (95\% CI. $84.1 \%-99.6 \%)$ in the 14-day group $(\mathrm{p}=0.039)$. Adverse events were not significantly different between the two groups. Conclusion: A 14-day course was more effective than 10-day course of triple therapy as first-line for eradication of H.pylori infection in an Indonesian population.
\end{abstract}

Keywords: Helicobacter pylori- duration- triple therapy- eradication- Indonesian population

Asian Pac J Cancer Prev, 21 (1), 19-24

\section{Introduction}

Helicobacter pylori (H.pylori) infects a large proportion of the world's population. Most affected individuals are asymptomatic. However, $15-20 \%$ of the case will be related peptic ulcers and $1-4 \%$ will grow as gastric malignancy. The eradication of H.pylori infection is one of the successful keys of peptic ulcer therapy and prevention of gastric malignancy. (Atherton and Blaser, 2013).

Nowadays, American College of Gastroenterology (ACG), Asia Pacific of Gastroenterology (APAGE), World Gastroenterology Organization (WGO), and The Indonesian Society of Gastroenterology (Perkumpulan Gastroenterologi Indonesia / PGI) recommend triple therapy, consist of proton pump inhibitor, Amoxicillin, and Clarithromycin, for the first-line therapy of $\mathrm{H}$. pylori infection. Yet, questions remain regarding the optimal duration of triple therapy. For Asia, APAGE and PGI recommend triple therapy for 7-14 days. (Chey and Wong, 2007; Fock et al., 2009; Hunt et al., 2010; Syam et al., 2017).

Successfulness of $\mathrm{H}$. pylori eradication with the 7-day course triple therapy is declining. A Meta-analysis by $\mathrm{Li}$ et al., (2015) showed that longer than 7-day triple therapy course generates $73 \%$ eradication rate, while 10-to-14-day course generates $81 \%$. Other meta-analysis conducted by Yuan et al, (2013) also indicated that the prolonging therapy is related with better eradications rates, whereas proportion of eradication rates of the 7-day, 10-day and 14 -day course triple therapies were $76 \%, 80 \%$ and $86 \%$.

Studies comparing directly between 10-day and 14-day course of triple therapy were limited and debaTable. A study by Fennerty et al., (1998), there was no difference in H. pylori eradication rates between 10-day and 14-day course triple therapy. Another study by Chen and Fallone (2015), obtained different eradication rates of H.pylori infection between two groups, $82.7 \%$ for 14 -day course

${ }^{1}$ Department of Internal Medicine, ${ }^{2}$ Division of Gastroenterology, ${ }^{3}$ Clinical Epidemiology Unit, Department of Internal Medicine, Faculty of Medicine, Universitas Indonesia, Cipto Mangunkusumo Hospital, ${ }^{4}$ Cilincing District General Hospital, Jakarta, Indonesia.*For Correspondence: ari_syam@hotmail.com 
and $45.2 \%$ for 10 -day course. Thus, this study compares the effectiveness between 10-day course and 14-day course triple therapy in eradication of H.pylori infection in an Indonesian population.

\section{Materials and Methods}

\section{Study subjects and Materials}

A prospective double-blinded randomized clinical trial was conducted from October 2016 to June 2017 in Cipto Mangunkusumo Hospital, Jakarta; Cilincing District General Hospital, Jakarta; and West Nusa Tenggara General Hospital, Mataram, Indonesia. The following criteria applied to the patients to be admitted to the study : Indonesian people, aged over 18 years, signed informed consent, and positive for Helicobacter pylori infection from UBT or histopathology biopsy from esophagoduodenocopy. We excluded patients obtained previous H.pylori therapy, abnormal ALT, arrhythmia, prolonged QT, and pregnant or breastfeeding woman.

\section{According to the two independent sample size formula as follows}

with the proportion $63.6 \%$ and expected proportion $91.4 \%$ (from previous studies), we obtained that minimum sample is 34 patients for each group.11,12

Patients did not use proton pump inhibitor or antibiotics for 2 weeks before UBT or esophagoduodenoscopy. Patients with positive results were randomized using Microsoft Excell 2015 @, into either group A or group B. Patients and physicians did not know where the patients were given triple therapy as Rabeprazole $20 \mathrm{mg}$, Amoxicillin 1,000 mg, and Clarithromycin $500 \mathrm{mg}$ twice daily for 14 days or Rabeprazole $20 \mathrm{mg}$, Amoxicillin $1,000 \mathrm{mg}$, and Clarithromycin $500 \mathrm{mg}$ twice daily 10 days plus 4 days placebo. Only the pharmacist knew the allocation of drugs given to the patients group A and group B (blinding process). We also documented patients' demographics (sex, age, ethnic, level of education, and salary), smoking habits, nutritional status, and comorbid disease. Patients' sex and age were based on their ID Card at the time the study was done. Patients' ethnic was asked to them (Javanese, Sundanese, Buginese, Batak, Balinese, Betawi, Malay, and others). Level of educational was the patient's last education (Low for not graduated or Elementary School; Medium for Junior High School or Senior High School; High : Diploma, Undergraduate, Graduate, or Post-graduate). Salary was the patient's monthly income (Below or Above the 2016 Regional Minimum Income. The 2016 Regional Minimum Income for Jakarta was IDR. 3,100,000. (about USD 235.00) per month and Mataram was IDR 1,482,950 (about USD $115.00)$ per month. Smoking habits was asked to the patient at the time the study was done. Nutritional status was determined by patient's Body Mass Index (BMI) (underweight : BMI less than $18.5 \mathrm{~kg} / \mathrm{m}^{2}$; normal : BMI 18.5-22.9 kg/m²; Overweight : BMI 23.0-25.0 kg/m²; and Obesity : BMI above $25.0 \mathrm{~kg} / \mathrm{m}^{2}$ ). Comorbid disease was based on medical record (Type 2 Diabetes Mellitus (DM); Hypertension; Dyslipidemia; Coronary Artery Disease; Ashtma; Osteoarthritis; and other diseases). Through the research, patients obtained appropriate medical therapy for their comorbid disease. All patients were carefully monitored regarding their compliance and adverse effects (allergic, taste perversion, epigastric pain, headache, nausea, vomiting, and others). Patients were underwent UBT to evaluate the successfulness of eradication, at least 4 weeks after finishing the treatment. In the end of the study, we opened the label and got that group A was 14-day course triple therapy and group B was 10-day course triple therapy.

This study protocol has approved by The Ethics Committee of the Faculty of Medicine, Universitas Indonesia, Jakarta with protocol number : 16-10-311 and registered at www.clinicaltrials.gov with ID number: NCT03134378.

\section{Statistical analysis}

Continous variables were stated as mean, while $95 \%$ Confidental Intervals were calculated for categorical variables using the standard normal approximation of the binomial distribution. Chi-square test $\left(X^{2}\right)$ or Fisher's exact test was performed to prove the significant differences of proportion of eradication between the 14-day course triple therapy and 10-day course triple therapy. Statistical analysis was performed using both an intention-totreat (ITT) analysis, in which a patients with missing eradication data was considered to be a treatment failure, and a per-protocol (PP) analysis, in which a patients with missing eradication data was excluded from calculation. Statistical analysis was performed using the SPSS $^{\circledR}$ software package version 22.0.

\section{Results}

A total of 79 patients acquired positive H.pylori infection. Three patients did not sign the informed consent and 1 patient had history of penicillin allergic, thus 75 patients met the criteria for study. The randomized process created 38 patients in group A and 37 patients in group B. At the end of, 4 patients ( 1 in the group $A$ and 3 in the group B) were lost to follow up. The physicians interpreting the results were blinded to the treatment allocation. Figure 1. depictes the research flow. All baseline characteristics were similar for the two treatment groups with respect to demographics (sex, age, ethnic, level of educational, and salary), smoking habits, nutritional status, and comorbid disease. Table 1 describes baseline characteristics between those two groups.

Using ITT analysis, we obtained that the group A eradication rate was $86.8 \%$ (95\% CI. $76.0 \%-97.5 \%)$ while the group B eradication rate was $67.6 \%(95 \% \mathrm{CI}$. $52.5 \%-82.6 \%)$, and statistically significant $(\mathrm{p}=0.046$; Chi-Square test). The ITT analysis is described in the Table 2. Expending PP analysis, we obtained that the group A eradication rate was 91.9\% (95\% CI. 84.1\%-99.6\%), whereas the group B eradication rate was $73.5 \%(95 \%$ CI. 58.6\%-88.3\%), and statistically significant ( $\mathrm{p}=0.039$; Chi-square test). The PP analysis is depicted in the Table 3. Adverse events (taste pervesion, nausea, vomiting, headache, fatigue, and diarrhea) were not significantly different between the two groups. Monitoring the adverse 
Table 1. Baseline Characteristics between Two Groups

\begin{tabular}{|c|c|c|}
\hline Variable & $\begin{array}{c}\text { 14-day Triple } \\
\text { Therapy } \\
(\mathrm{n}=38)\end{array}$ & $\begin{array}{c}\text { 10-day Triple } \\
\text { Therapy }+4 \text {-day } \\
\text { Placebo }(\mathrm{n}=37)\end{array}$ \\
\hline \multicolumn{3}{|l|}{ Sex; n (\%) } \\
\hline Male & $17(44.7)$ & $12(32.4)$ \\
\hline Female & $21(55.3)$ & $25(67.6)$ \\
\hline \multicolumn{3}{|l|}{ Age; years } \\
\hline \multirow[t]{2}{*}{ Mean } & 44.05 & 45.08 \\
\hline & $\begin{array}{c}(95 \% \mathrm{CI}: \\
39.26-48.84)\end{array}$ & $\begin{array}{c}(95 \% \mathrm{CI}: \\
39.94-50.23)\end{array}$ \\
\hline \multicolumn{3}{|c|}{ Classification of age; years (\%) } \\
\hline $18-30$ & $9(23.7)$ & $7(18.9)$ \\
\hline $30-40$ & $6(15.8)$ & $8(21.6)$ \\
\hline $40-50$ & $7(18.4)$ & $9(24.3)$ \\
\hline $50-60$ & $11(28.9)$ & $5(13.5)$ \\
\hline$>60$ & $5(13.2)$ & $8(21.6)$ \\
\hline \multicolumn{3}{|l|}{ Ethnic; n (\%) } \\
\hline Bugisnese & $11(28.9)$ & $11(29.7)$ \\
\hline Batak & $8(21.1)$ & $7(18.9)$ \\
\hline Javanese & $4(10.5)$ & $5(13.5)$ \\
\hline Betawi & $4(10.5)$ & $3(8.1)$ \\
\hline Sundanese & $3(7.9)$ & $3(8.1)$ \\
\hline Sasak & $3(7.9)$ & $3(8.1)$ \\
\hline Others & $5(13.1)$ & $5(13.5)$ \\
\hline \multicolumn{3}{|l|}{ Level of Education; n (\%) } \\
\hline Low & $9(23.7)$ & $10(27.0)$ \\
\hline Medium & $19(50.0)$ & $18(48.6)$ \\
\hline High & $10(26.3)$ & $9(24.3)$ \\
\hline \multicolumn{3}{|c|}{ Salary / Monthly income; n (\%) } \\
\hline $\begin{array}{l}\text { Below Regional Min } \\
\text { Income }\end{array}$ & $24(63.2)$ & $25(67.6)$ \\
\hline $\begin{array}{l}\text { Above Regional Min } \\
\text { Income }\end{array}$ & $14(36.8)$ & $12(32.4)$ \\
\hline \multicolumn{3}{|l|}{ Smoking habits; $\mathrm{n}(\%)$} \\
\hline Yes & $8(21.1)$ & $8(21.6)$ \\
\hline No & $30(78.9)$ & $29(78.4)$ \\
\hline \multicolumn{3}{|l|}{ Nutritional Status; n (\%) } \\
\hline Underweight & $5(13.2)$ & $4(10.8)$ \\
\hline Normal & $14(36.8)$ & $17(45.9)$ \\
\hline Overweight & $7(18.4)$ & $7(18.9)$ \\
\hline Obesity & $12(31.6)$ & $9(24.3)$ \\
\hline \multicolumn{3}{|l|}{ Comorbid Disease; n (\%) } \\
\hline Type 2 DM & $4(10.5)$ & $1(2.7)$ \\
\hline Hypertension & $6(15.8)$ & $2(5.4)$ \\
\hline Dyslipidemia & $1(2.6)$ & $3(8.1)$ \\
\hline Coronary Artery Disease & $2(5.3)$ & $1(2.7)$ \\
\hline Asthma & $1(2.6)$ & $1(2.7)$ \\
\hline Osteoarthritis & $2(5.3)$ & $1(2.7)$ \\
\hline
\end{tabular}

effects, we concluded that the most frequent of adverse effects is perversion taste. Patients felt flavorless taste when drinking mineral water. We find that the adverse effects between two groups tend to be the same. Table 4 reports the adverse effects.
Table 2. Intention-to-Treat Analysis

\begin{tabular}{|c|c|c|c|c|c|}
\hline \multirow{3}{*}{ Research Group } & \multicolumn{5}{|c|}{ Proportion of eradication } \\
\hline & \multicolumn{2}{|c|}{ Successful } & \multicolumn{2}{|c|}{$\begin{array}{l}\text { Failed/ } \\
\text { Lost-to- } \\
\text { follow up }\end{array}$} & \multirow[t]{2}{*}{$\mathrm{p}^{*}$} \\
\hline & $\mathrm{n}$ & $\%$ & $\mathrm{n}$ & $\%$ & \\
\hline $\begin{array}{l}\text { 14-day Triple Therapy } \\
(\mathrm{n}=38)\end{array}$ & 33 & 86.8 & 5 & 13.2 & \multirow[t]{3}{*}{0.046} \\
\hline $\begin{array}{l}\text { 10-day Triple Therapy } \\
+4 \text {-day Placebo }(n=37)\end{array}$ & 25 & 67.6 & 12 & 32.4 & \\
\hline Total & 58 & 77.3 & 17 & 22.7 & \\
\hline
\end{tabular}

*p, Chi-square test

Table 3. Per-Protocol Analysis

\begin{tabular}{lcccccc}
\hline Research Group & \multicolumn{5}{c}{ Proportion of Eradication } \\
& Successful & \multicolumn{2}{c}{ Failed } & $\mathrm{p}^{*}$ \\
& $\mathrm{n}$ & $\%$ & $\mathrm{n}$ & $\%$ & \\
\hline $\begin{array}{l}\text { 14-day Triple Therapy } \\
(\mathrm{n}=37)\end{array}$ & 34 & 91.9 & 3 & 8.1 & 0.039 \\
$\begin{array}{l}\text { 10-day Triple Therapy } \\
+ \text { 4-day Placebo (n=34) }\end{array}$ & 25 & 73.5 & 9 & 26.5 & \\
Total & 59 & 83.1 & 12 & 16.9 & \\
\hline * ph Chi-square test & & & & & &
\end{tabular}

\section{Discussion}

The proportion of female patients were higher than other study. Kawakubo et al., (2016), showed that complaints in the upper gastrointestinal symptoms were more frequent in female than male. In both groups, the number of female patients were similar. H.pylori infected all ages, related with previous studies conducted by Goto et al., (2016) and Darnindro et al., (2015). Many studies also showed that H.pylori infection spread across all ages. Furthermore, it was uncommon to find the infection in the children who inherited the infection from their parents. We obtain comparable age between both groups.

Bugisnese and Batak were the most ethnics infected by H.pylori in this research. This finding also confirmed the findings from Goto et al., (2016) and Darnindro et al., (2015). in the previous study in Indonesia. Goto et al., (2016), noticed that eating using hand was more frequent in Buginese and Batak than other ethnics, thus they proned to the H.pylori infection. We found that H.pylori infection accross all of the education levels. This was related with the study from Darnindro et al., (2015), showing that H.pylori infection spreads across all education levels.

Table 4. Adverse Effects During Triple Therapy Given to Patients

\begin{tabular}{lcc}
\hline $\begin{array}{l}\text { Adverse } \\
\text { Effect; } \mathrm{n}(\%)\end{array}$ & $\begin{array}{c}\text { 14-day Triple } \\
\text { Therapy }(\mathrm{n}=38)\end{array}$ & $\begin{array}{c}\text { 10-day Triple Therapy } \\
+ \text { 4-day placebo }(\mathrm{n}=37)\end{array}$ \\
\hline taste pervesion & $9(23.7)$ & $7(18.9)$ \\
nausea & $7(18.9)$ & $7(19.4)$ \\
vomiting & $1(2.6)$ & $1(2.7)$ \\
headache & $0(0)$ & $1(2.7)$ \\
fatigue & $2(5.3)$ & $3(8.1)$ \\
diarrhea & $0(0)$ & $2(5.4)$ \\
\hline
\end{tabular}

Asian Pacific Journal of Cancer Prevention, Vol 21 


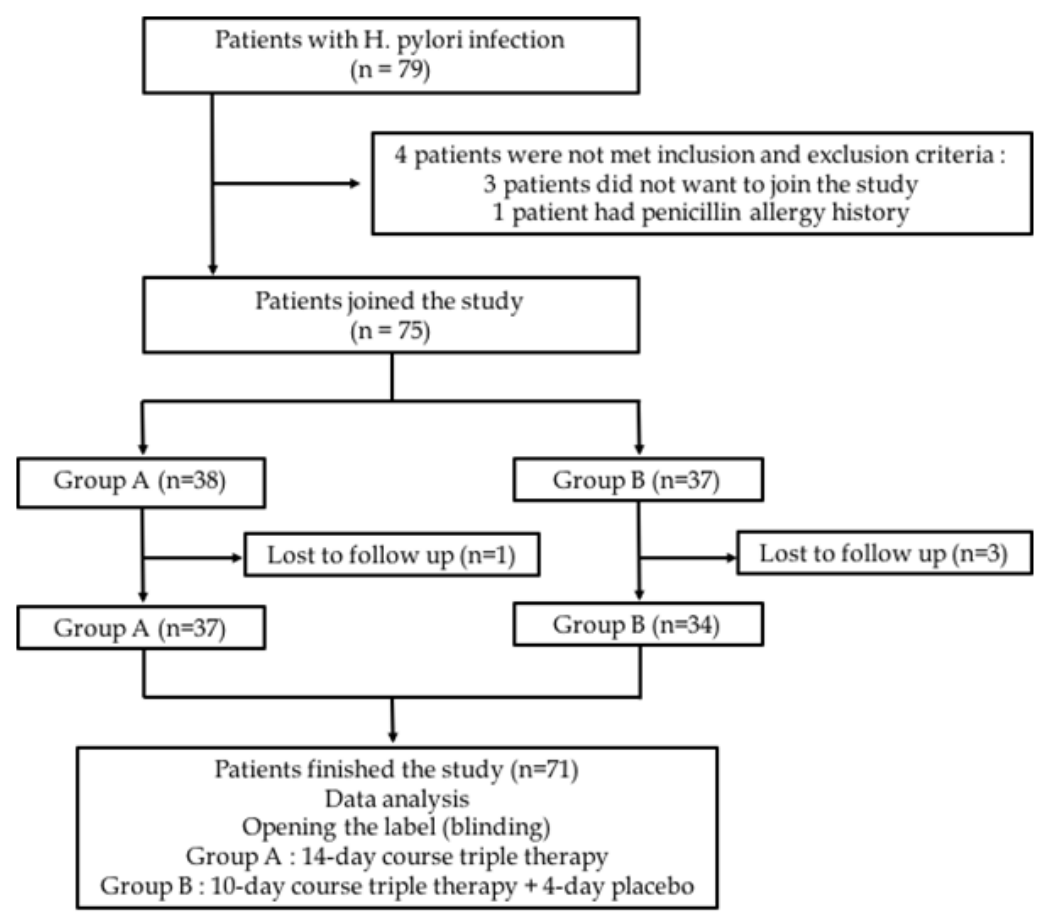

Figure 1. Research Flow Diagram

We expected salary was a risk factor of the H.pylori infection. Most of our patients had monthly income below 2016 Regional Minimum Income. According to Bruce (2008), education level and monthly income were risk factors causing the H.pylori infection. Indeed, this hypothesis was debaTable because some studies explained that low education level and low income were associated with the high proprotion of H.pylori infection, while other studies proved no association between low education and income levels with H.pylori infection. Nutritional level was also considered as a success factor of H.pylori infection. Abdullahi et al., (2008), showed that overweight and obesity patients had lower successful for eradication of H.pylori infection. Our study has similar proportion of nutritional status in the both group. 16,17

Smoking was an important variable in H.pylori infection. The study conducted by Suzuki et al., (2016), exhibited that smoking could decrease the successful for eradication of H.pylori infection. Our study has similar proportion of smoking in the both group. We also suggested that the patients reduced their smoking frequency during the research period (Syam et al., 2017).

With ITT analysis, we found that the eradication rate of the H.pylori infection in the 14-days course triple therapy was $86.6 \%$, higher than 10 -days course $67.6 \%$ $(p=0.046$; Chi-square test). Our finding was consistent with Chen and Fallone (2015), whereas the eradication rate of the H.pylori infection using 14-days course triple therapy was $82.7 \%$, higher than 10 -days course which was only $45.2 \%$. Using per-protocol analysis, we found that the eradication rate of the H.pylori infection in the 14-days course triple therapy is $91.9 \%$, higher than 10 days course triple therapy which is only $73 . \%(p=0.039)$. Our finding in the difference is consistent with Chen and Fallone (2015). whereas the eradication rate of the H.pylori infection using 14-days course triple therapy is
$91.5 \%$, and 10 -day course was only $63.6 \%$. Our study is different from Chen and Fallone (2015), because our design study was double-blinded clinical trials and we have only 5.3 percent lost-fo-follow up respondents, and we used Rabeprazole as proton pump inhibitor.

Fennerty et al., (1998), has different conclusion from our study. They concluded that there is no significant different between 10-day course and 14-day course triple therapy. We should note that their study was conducted 19 years ago, when the research on H.pylori infection had just been started and antibiotical resistance were lower than nowadays. Furthermore, they used Lansoprazole as the proton pump inhibitor.

Comparing with the study from $\mathrm{Li}$ et al., (2015), it was clearly shown that our research was in line. We could see in their analysis demonstrating the increment of the eradication rate of the H.pylori infection in the prolonging triple therapy group. However, Li et al., (2015) demonstrate only $6 \%$ difference in the proportion between 14-day course and 10-day course triple therapy. This findings were thought because of very diverse ethnics, geographical locations, periods and proton pump inhibitor used in their research. Furthermore, their results were obtained from additional analysis, instead of direct comparisons between 14-day course and 10-day course triple therapy.

Our study justified recent recommendation from American College of Gastroenterology (ACG) on February 2017. ACG showed that the first line therapy that has been used and approved by United States Food and Drug Administration (FDA) was triple therapy using proton pump inhibitor, Clarithromycin $500 \mathrm{mg}$, and Amoxicillin 1,000 mg twice daily for 14 days. However, we should note that the patients had to be asked regarding their previous macrolide history and the Clarithromycin resistance was less than $15 \%$. Therefore, APAGE and PGI 
need to issue a new recommendation on the duration of triple therapy for H.pylori infection eradication in Asia, especially in Indonesia (Chey et al., 2017).

According to the theory, the duration of triple therapy was related to the eradication rate. This was in line with previous research documenting that 3-day course and 5 -day course triple therapies have been abandoned. Furthermore, 7-day course triple therapy was no longer recommended due to low eradication rate. However, we might ignore the theory because some of the determinants causing the failure for eradication of the H.pylori infection are the antibiotics resistance and low compliance of the patient. (Chey and Wong, 2007; Fock et al., 2009; Hunt et al., 2010; Syam et al., 2017).

The bacteria could still live in the gaster that was acid by producing urease enzymes that dissolve urea becoming ammonia. The ammonia would be used to protect the bacteria from the acid. H.pylori can be bound in all parts of gaster (fundus, antrum or corpus). If the lumen of the gaster was acid, the bacteria tent to be found in antrum area (far from antibiotics' reach). If the gastric acid was minimized, the bacteria tent to be found in the corpus. Thus, the bacteria could be easily reached by the antibiotics (Kusters et al., 2006).

The bacteria could naturally defend themselves by transforming them from spiral to small coccoid. The small coccoid did not degenerate. Thus, this causes difficulties in the eradication. The small coccoid would be back to spiral form in the next 1-2 weeks. Therefore, the 1-2 weeks period became a good reference for the duration of triple therapy for the eradication of Helicobacter pylori infection. If the therapy was conducted for the period equals or less than a week, the bacteria might defend themselvers by the trasformation process. If the therapy was conducted for the 10-day period, the drugs would attack the bacteria only in few days (and then the bacteria would defend in the remaining days). If the therapy was conducted for the 14-day period, the drugs would "fight" the bacteria in the longer period. Thus, the drugs could still attack the bacteria when the they have transformed back into original form. The clarithromycin resistance was $9.1 \%$ in Indonesia, but the prevalence of clarithromycin resistance in Java island (Jakarta is a part of Java island) was $21.4 \%$. Thus, it was thougt that triple therapy should be given with a longer duration in this population (Kusters et al., 2006; Miftahussurur et al., 2016).

In conclusion, the 14-day course was better than 10-day course triple therapy for eradication of the H.pylori infection in an Indonesian population. There were no differences in adverse effects that occurred in both groups.

\section{Acknowledgements}

We gratefully thank to Directorate of Research and Community Service (Direktorat Riset dan Pengabdian Masyarakat) Universitas Indonesia for International Indexed Publications for Students' Final Assignments Grant (Hibah Publikasi Internasional Terindeks untuk Tugas Akhir Mahasiswa) 2016 that fund this study.
Competing interests

None of the authors have potential conflict of interests.

\section{References}

Abdullahi M, Annibale B, Capoccia D, et al (2008). The eradication of Helicobacter pylori is affected by Body Mass Index (BMI). Obes Surg, 18, 1450.

Atherton JC, Blaser MJ (2013). Helicobacter pylori infections. In: Longo DL, Fauci AS, Langford CA. Harrison's gastroenterology and hepatology 2nd ed. New York: McGraw Hill Education. 2013. pp 262-8.

Bruce MG, Maaroos HI (2008). Epidemiology of helicobacter pylori infection. Helicobacter, 12, 1-6.

Chen YI, Fallone CA (2015). A 14-day course of triple therapy is superior to a 10-day course for the eradication of Helicobacter pylori: A canadian study conducted in a 'real world' setting. Can J Gastroenterol Hepatol, 5, 7-10.

Chey WD, Leontiadis GI, Howden C, Moss SF (2017). ACG clinical guideline: treatment of helicobacter pylori infection. Am J Gastroenterol, 112, 212-38.

Chey WD, Wong BCY (2007). American college of gastroenterology guideline on the management of helicobacter pyori infection. Am J Gastroenterol, 102, 1808-25.

Darnindro N, Syam AF, Fauzi A, Rumende C (2015). Seroprevalence and socio-demographic factors of helicobacter pylori infection in patients with dyspeppsia in Kalibartu Primary Health Care North Jakarta. Acta Med Indones, 47, 297-303.

Fennerty MB, Kovacs TOG, Krause R, et al (1998). A comparison of 10 and 14 days of lansoprazole triple therapy for eradication of Helicobacter pylori. Arch Intern Med, 158, 1651-6.

Fock KM, Katelaris P, Sugano K, et al (2009). Second Asiapacific consensus guidelines for helicobacter pylori infection. JGHF, 6, 1587-1600.

Goto Y, Syam AF, Darnindro N, Hapsari FCP (2016). Prevalence and risk factors for helicobacter pylori infection among healthy inhabitatns in northern Jakarta, Indonesia. Asian Pac J Cancer Prev, 17, 4747-53.

Hunt RH, Xiao SD, Megraud F, et al (2010). World gastroenterology organization global guidelines Helicobacter pylori in developing countries. World Gastroenterol Org, 2010, 1-15.

Kawakubo H, Tanaka Y, Tsuruoka N, et al (2016). Upper gastrointestinal symptoms are more frequent in female than male young healthy Japanese volunteers as evaluated by questionnaire. J Neurogastroenterol Motil, 22, 248-53.

Kusters JG, ven Vliet AHM, Kuipers EJ (2006). Pathogenesis of helicobacter pylori infection. Clin Microbiol Rev, 2006, 449-90.

Li BZ, Threapleton DE, Wang JY, et al (2015). Comparative effectiveness and tolerance of treatments for helicobacter pylori: systematic review and networks meta-analysis. $B M J$, 351, 1-11.

Miftahussurur M, Syam AF, Nusi IA, et al (2016). Surveillance of helicobacter pylori antibiotic susceptibility in Indonesia: different resistance types among regions and with novel genetic mutations. PLoS One, 11, 1-17.

Suzuki T, Matsuo K, Ito H, et al (2016). Smoking increases the treatment failure for helicobacter pylori eradication. Am J Med, 119, 217-24.

Syam AF, Abdullah M, Rani AA, Nurdjanah S, Adi P Djumhana (2010). A comparison of 5 or 7 days of rabeprazole triple therapy for eradication of heliobacter pylori. Med J Indones, 2, 113-7.

Asian Pacific Journal of Cancer Prevention, Vol 21 
Ryan Herardi et al

Syam AF, Simadibrata M, Makmun D, et al (2017). National consensus on management of dyspepsia and helicobacter pylori infection. Acta Med Indones, 49, 279-87.

Yuan Y, Ford AC, Khan KJ, et al (2013). Optimum duration of regimens for Helicobacter pylori eradication. Cochrane Database Syst Rev, 2013, 1-421.

\section{(c) (i) 8)}

This work is licensed under a Creative Commons AttributionNon Commercial 4.0 International License. 